DOI: 10.1002/adsc.201((will be filled in by the editorial staff))

\title{
Modular ligands for dirhodium complexes facilitate catalyst customization
}

\author{
Daniel G. Bachmann, ${ }^{a}$ Pascal J. Schmidt, ${ }^{a}$ Stefanie N. Geigle, ${ }^{a}$ Antoinette Chougnet, ${ }^{a}$ \\ Wolf-Dietrich Woggon, ${ }^{a}$ and Dennis G. Gillingham ${ }^{a *}$
}

a Department of Chemistry, University of Basel, St. Johanns-Ring 19, 4056 Basel, Switzerland. Fax: (+41)-61-2670976; Phone: (+41)-61-267-1148; e-mail: dennis.gillingham@unibas.ch

Received: ((will be filled in by the editorial staff))

Supporting information for this article is available on the WWW under http://dx.doi.org/10.1002/adsc.201\#\#\#\#\#.((Please delete if not appropriate))

\begin{abstract}
Although stereoselectivity is often the focus of ligand optimizations in catalysis, ligand modularity can be used to control many other properties of catalysts. For example solubility, amenability to purification, and steric shielding of sensitive catalytic intermediates are all important, but seldom appreciated, functions of ligands. We describe a brief and modular approach to various homo- and heteroleptic lantern-type rhodium(II) complexes and perform benchmarking studies with the new catalysts in common rhodium(II)-catalysed reactions. We demonstrate the power of ligand modularity by creating catalysts customized for aqueous catalysis or for applications in chemical biology.
\end{abstract}

Keywords: Rhodium; Carboxylate Ligands; C-H activation; Fluorescent probes; Water chemistry

We became interested in tethered bis-dicarboxylate rhodium(II) complexes in the context of our recent studies on metal-carbenoid based nucleic acid alkylation. ${ }^{[1]}$ To further develop this technology we needed a set of rhodium(II) complexes with stable and modular ligands that still performed well in typical rhodium(II)-catalyzed reactions, particularly in water. Most rhodium complexes are highly insoluble in water and not readily amenable to modification. ${ }^{[2]}$ We settled on the tethered bis-carboxylate structure because we thought its increased stability, ${ }^{[3]}$ as well as its potential to intercalate DNA, ${ }^{[4]}$ could deliver performance improvements in comparison with $\mathrm{Rh}_{2}(\mathrm{OAc})_{4}$. The ligand introduced by Du Bois and co-workers ${ }^{[5]}$ was chosen as a starting scaffold but two major problems prompted us to change tack: first, creating a library of ligands proved synthetically cumbersome and second, controlling mono- versus double-substitution in the rhodium carboxylates was unpredictable. Inspired by previous work from Bonar-Law in creating dirhodiumbased metal-organic architectures, ${ }^{[6]}$ we examined dicarboxylate ligands derived from 1,3-benzenediols (see Scheme 1). This construct maintains the essential structural features of the espino ligand, but has the advantage of modularity since numerous 1,3benzenediol derivatives are commercially available.
Moreover, since Bonar-Law used these dicarboxylates to create well-defined supramolecular objects the coordination of each ligand needed to be precisely controlled, providing valuable information for our own studies.
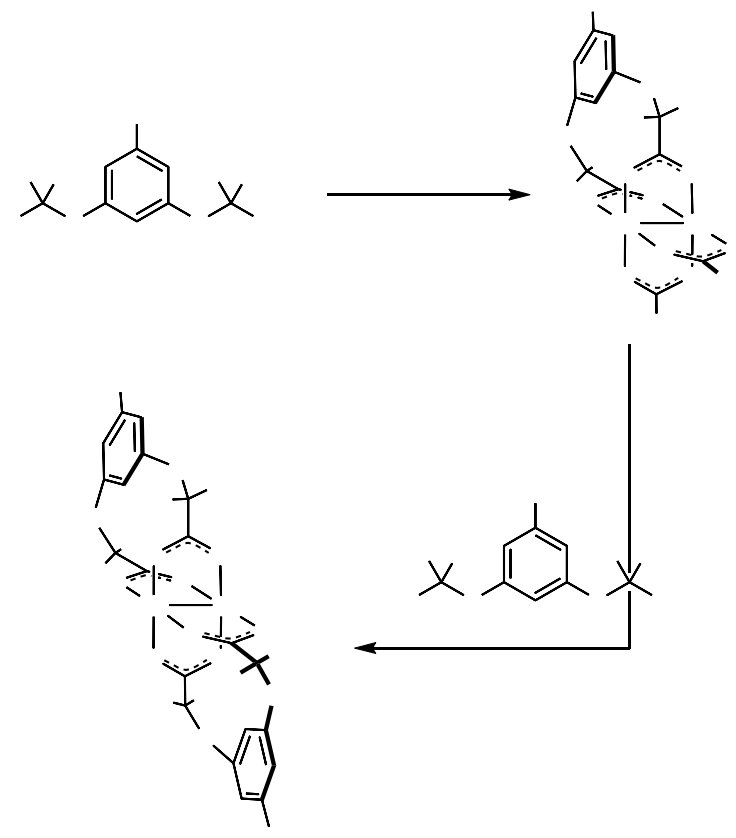

Scheme 1. Modular approach towards mono- and bissubstituted rhodium(II) complexes. See the ESI pages S2S6 and S14-S19 for detailed protocols.

The syntheses of the various homo- and heteroleptic rhodium(II) complexes we have prepared are shown in Scheme 1. Using the conditions developed by BonarLaw the monobiscarboxylate complex 1 is obtained in $60 \%$ yield after three hours in N,N-dimethylaniline. However, for ligands with electron withdrawing groups at C5 (10b-d) milder conditions were necessary: $\mathrm{Rh}_{2}(\mathrm{OAc})_{2}(\mathrm{TFA})_{2}$ in DCE at $60-70^{\circ} \mathrm{C}$ with small amounts of EtOAc as co-solvent led to acceptable yields (31\% for $\mathbf{2}, \mathbf{2 7} \%$ for $\mathbf{3}$, and $35 \%$ for 
4). The yields are low to moderate, but this is a typical feature of syntheses of rhodium(II) complexes; in many cases substantial amounts of starting material can be recovered and recycled. Unfortunately, attempts to perform a second substitution to access the heteroleptic complexes using Bonar-Law's conditions led to low yields and mixtures of products. We therefore turned to Taber's original procedure involving a portion-wise addition of the ligand. ${ }^{[7]}$ Through the combination of these protocols we have been able to synthesize new rhodium(II) complexes containing a variety of functional groups (Scheme 1).

Shown in Scheme 2 is the full collection of dicarboxylate ligands 10a-e we have synthesized thus far starting from commercial C5-substituted 1,3benzenediols 8a-e. Diesters 9a-e were synthesized by double O-alkylation with ethyl-2-bromoisobutyrate and a mixture of $\mathrm{K}_{2} \mathrm{CO}_{3}$ and $\mathrm{Cs}_{2} \mathrm{CO}_{3}$ in yields between 77 and 99\%. Final hydrolysis was accomplished with $\mathrm{LiOH}$ to afford the desired dicarboxylate ligands 10ae in excellent yield, bearing a variety of functional groups poised for further modification such as amide bond formation (2 or $\mathbf{6}$ ), Pd-catalyzed cross coupling (3) or condensation reactions $(4,6,7)$.

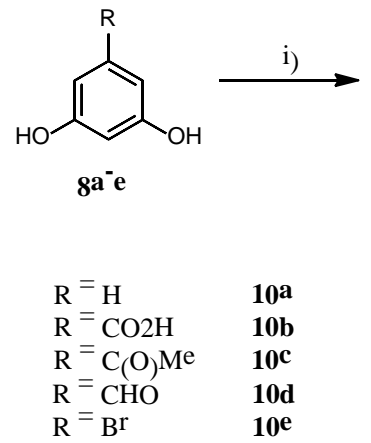

1. Compounds 8a-e are commercially available. i) Ethyl-2-bromoisobutyrate, $\mathrm{K}_{2} \mathrm{CO}_{3}$, $\mathrm{Cs}_{2} \mathrm{CO}_{3}, \mathrm{DMF}, 80^{\circ} \mathrm{C}, 12 \mathrm{~h}, 47-82 \%$ ii) $\mathrm{LiOH} \cdot \mathrm{H}_{2} \mathrm{O}$, $\mathrm{MeOH} / \mathrm{H}_{2} \mathrm{O} 2: 1,60^{\circ} \mathrm{C}, 3 \mathrm{~h}, 79-99 \%$ or THF $/ \mathrm{H}_{2} \mathrm{O}$ 1:1, $60^{\circ} \mathrm{C}, 20 \mathrm{~h}, 77-84 \%$ for $\mathbf{1 0 b}$ and 10e, respectively.

To probe the impact of the ligand on catalysis dirhodium(II) catalysts 5, 6, and 7 were tested in a typical intramolecular nitrene insertion reaction of sulfamate ester 11 (Table 1). Catalyst 5 leads to reaction at a similar rate as the Du Bois catalyst (see entries $1 \& 2$ ); only at $0.1 \mathrm{~mol} \%$ loading does the $\mathrm{Du}$ Bois system prove superior, ${ }^{[5]}$ still delivering complete conversion while 5 stalls at 35\% (data not shown). For operational simplicity and to allow comparisons at early time points reactions with catalysts 5-7 were also run at $25{ }^{\circ} \mathrm{C}$. At $25{ }^{\circ} \mathrm{C} 5$ reached complete conversion in 2 hours (entry 3), while 6 required 4 hours (entry 4). Catalyst 7 performed best of all, giving complete conversions at 60 minutes (entry 5). Catalyst 7 was further tested with some potential interfering additives to determine its robustness. ${ }^{[8]}$ We chose protic or Lewis basic additives since our primary goals are for

aqueous catalysis. Although methanol and acetic acid both attenuate the reactivity of 7 , complete conversions were still achieved in reasonable reaction times (entries 6 \& 7). The powerful Lewis base trimethylamine, however, inhibited the reaction (entry 8). The superiority of catalyst 7 in nitrene insertion may be a result of the more electron deficient character of the ligand, which would make the catalyst difficult to oxidize. Du Bois has shown that oxidative damage to catalysts is the primary mode of catalyst deactivation in nitrene insertion. ${ }^{[9]}$

Table 1. Benchmarking of catalysts in a nitrene insertion

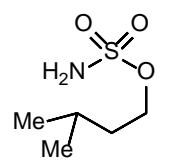

11

\begin{tabular}{ccccc}
\hline entry & cat. & additive & $\begin{array}{c}\text { Temp } \\
\left({ }^{\circ} \mathrm{C}\right)\end{array}$ & $\begin{array}{c}\text { time } \\
\left.(\mathrm{min})^{\mathrm{a}}\right)\end{array}$ \\
\hline 1 & $\mathbf{5}$ & - & 40 & $45^{\mathrm{b})}$ \\
2 & $\mathrm{Rh}_{2}(\mathrm{esp})_{2}$ & - & 40 & 45 \\
3 & 5 & - & 25 & $120^{\mathrm{c})}$ \\
4 & $\mathbf{6}$ & - & 25 & $\left.240^{\mathrm{c}}\right)$ \\
5 & 7 & - & 25 & $60^{\mathrm{c})}$ \\
6 & 7 & $\left.\mathrm{MeOH}^{\mathrm{c}}\right)$ & 25 & $120^{\mathrm{c}}$ \\
7 & 7 & $\mathrm{AcOH}$ & 25 & $240^{\mathrm{c})}$ \\
8 & 7 & $\mathrm{NEt}$ & 25 & n.r. ${ }^{\mathrm{c})}$ \\
\hline
\end{tabular}

a) time to reach $\geq 95 \%$ conversion; for a complete tabulation of time-point measurements see the ESI pages S7-S8; b) $98 \%$ isolated yield after chromatography; c) determined by ${ }^{1} \mathrm{H}$ NMR monitoring of the reactions in $\mathrm{CD}_{2} \mathrm{Cl}_{2}$.

In a second set of benchmarking experiments the new set of catalysts were tested in C-H insertion reactions to make $\beta$ - or $\gamma$-lactams (see 14a and 14b in Table 2). ${ }^{[10]}$ Comparison of entries 1-4 indicate that 5 performed best for $\beta$-lactam formation by $\mathrm{C}-\mathrm{H}$ insertion. This trend was also seen in the formation of a $\gamma$-lactam (cf. entries 8-11), although with this substrate 7 also worked well. The reaction times of 20 and 10 minutes for the reactions in entries 2 and 9 respectively are rapid for this reaction class. As a point of comparison the conditions in entry 8 are the previous best results for this transformation; here higher loading ( $3 \mathrm{~mol} \%)$, higher temperature $\left(70{ }^{\circ} \mathrm{C}\right.$ in toluene), and a longer reaction time were needed (60 minutes). 
Table 2. Benchmarking of catalysts in C-H insertion reactions

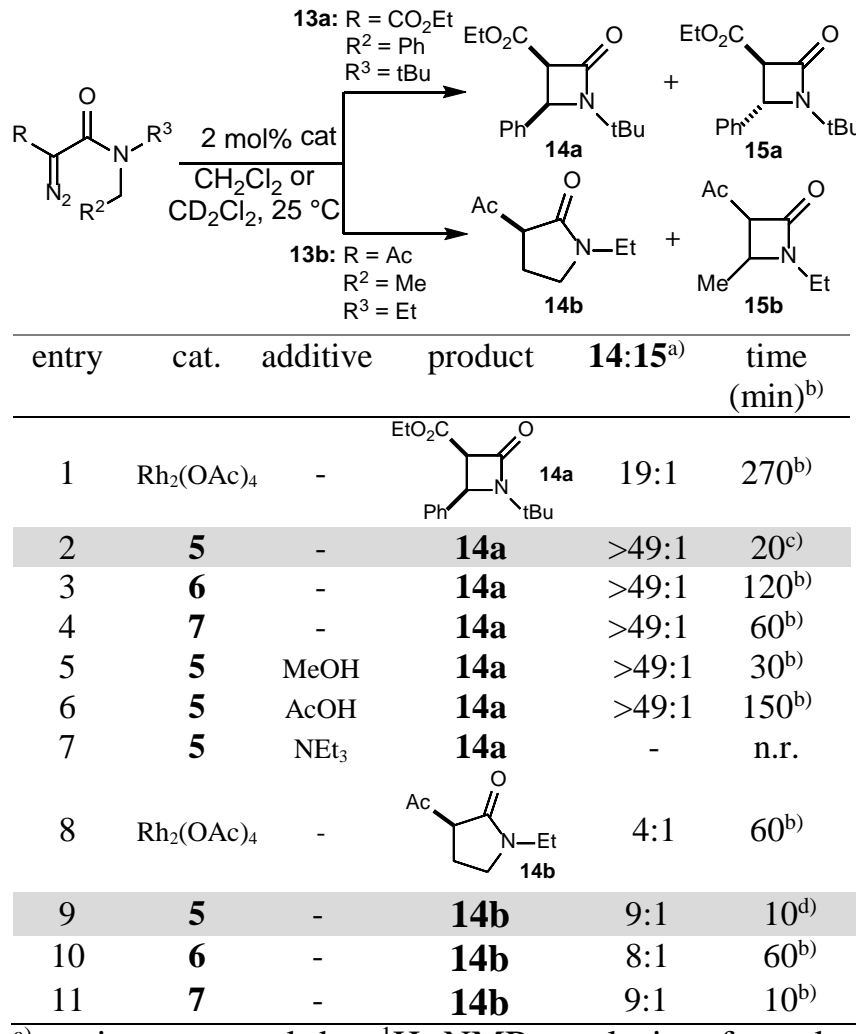

a) ratio measured by ${ }^{1} \mathrm{H}$ NMR analysis of crude reaction mixtures; b) time to reach $\geq 95 \%$ conversion according to ${ }^{1} \mathrm{H}$ NMR monitoring of the reactions in $\mathrm{CD}_{2} \mathrm{Cl}_{2}$; for a complete tabulation of intermediate time-points see the ESI pages S8-9; ${ }^{\text {c) }} 76 \%$ isolated yield after silica gel chromatography; d) $80 \%$ isolated yield after silica gel chromatography.

The modularity of the catalyst system opens new vistas in controlling rhodium-carbene chemistry. For example, although aqueous rhodium(II) catalysis is well-established, moderate water solubility limits the scope of most catalysts. Catalysis in water has therefore been limited to soluble variants, ${ }^{[11]}$ systems that contain cosolvents or detergents, ${ }^{[12]}$ or for catalysts bearing peptide ligands. ${ }^{[13]}$ The emerging importance of rhodium catalysis in chemical biology demands that more efficient water-soluble systems be developed. ${ }^{[14]}$ The heteroleptic dirhodium(II) complex 6 bearing a ketone functionalized ligand (10c) and a carboxylate functionalized ligand (10b) was found to be completely water soluble above the $\mathrm{pK}_{\mathrm{a}}$ of the carboxylate. This simple feature of complex 6 demonstrates the power of modularity in controlling the bulk properties of a catalyst. As a proof-of-concept for the potential of $\mathbf{6}$ in aqueous catalysis we tested the $\beta$-lactam formation under aqueous conditions. In the intramolecular C-H insertion catalyst 6 required lower loading $(0.5 \%$ vs $1-2 \%)$ and less time (10 min vs $0.5-$ 24h) than the previous best catalyst. ${ }^{[11]}$ Dirhodium(II) catalysts with high TOF in water are rare and therefore catalyst 6 represents a good candidate for future development in aqueous catalysis (an additional example of 6's potential in aqueous catalysis is provided in the ESI page S11).

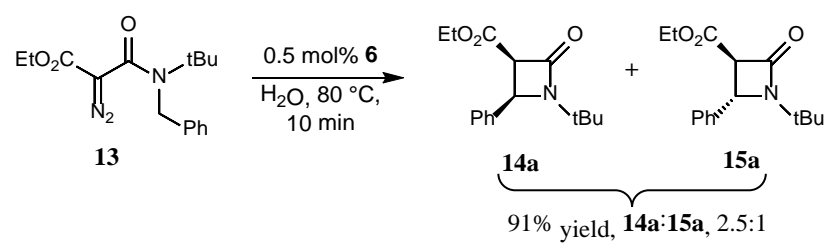

Scheme 3 Aqueous intramolecular C-H insertion with 6

We designed the ligand to combine structural flexibility without perturbing rhodium's primary ligand sphere, thus facilitating sophisticated modifications of the rhodium complexes (Table 3). Aldehyde-bearing complex $\mathbf{4}$ was condensed with a variety of hydrazide derivatives of small molecules that are important in chemical biology to create dirhodium(II) complexes with tailored properties. In particular conjugates with biotin, folic acid, maleimide, and Hoechst dye were all prepared without event. The maleimide and biotin complexes could be used in metalloenzyme development; ${ }^{[15]}$ while biotin could also be used for directing the catalyst to histones, ${ }^{[16]}$ potentially offering a way to modify them.

Table 3. Conjugation of complex 4 with a variety of useful small molecules
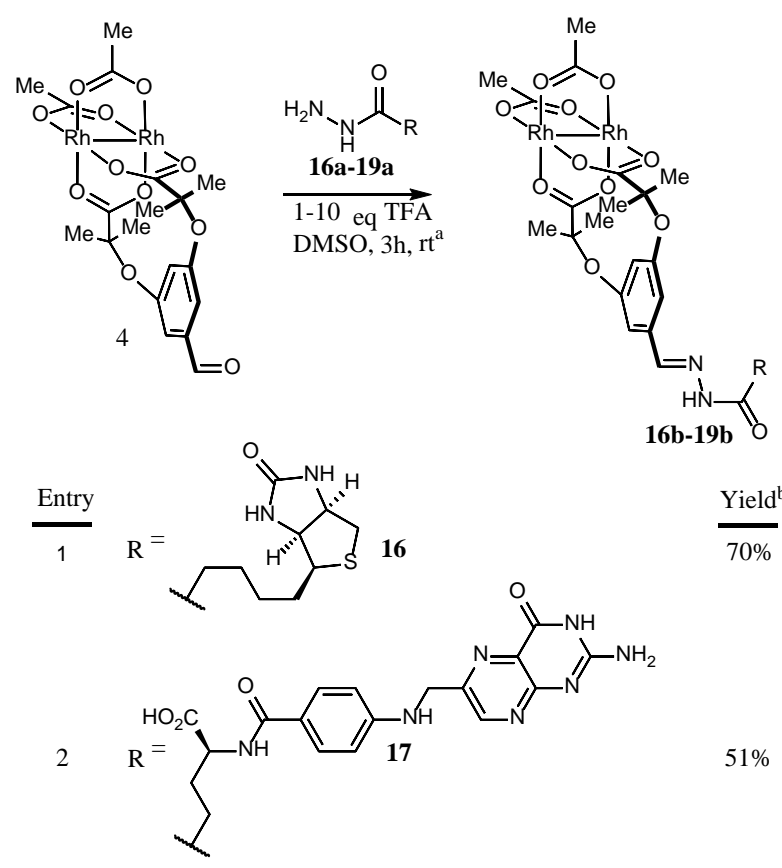

$51 \%$

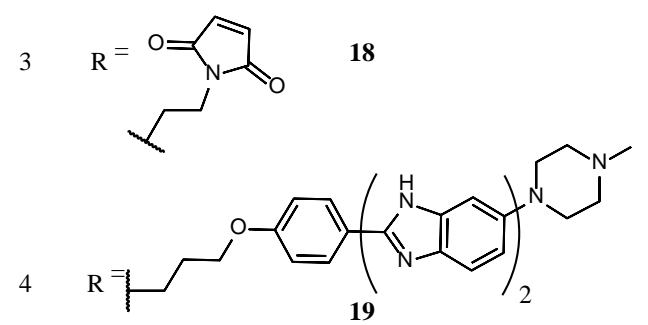

$65 \%$

$62 \%$

a) Please see the ESI for detailed reaction conditions. b) Refers to isolated yield after preparative reverse-phase HPLC. 
Many dirhodium(II) complexes have been shown to have DNA binding properties comparable with cisplatin; ${ }^{[4]}$ and the folate receptor is known to be overexpressed on cancer cells due to increased nutrient requirements. ${ }^{[17]}$ By combining these properties, folate-rhodium conjugates might therefore provide cancer-selective cytotoxins. The $\gamma$-acid of folate has previously been shown to be amenable to modification without interfering with receptor binding ${ }^{[18]}$ and we were pleased to find that a hydrazide installed at this position led to smooth and selective condensation with complex 4 (51\% yield, entry 2, Table 1).

It has recently been shown that fluorescently labelled dirhodium(II) complexes are taken up by cells and accumulate in lysosomes and mitochondria. ${ }^{[19]}$ No dirhodium(II) could be detected in the nucleus, an unfortunate reality given that dirhodium(II)'s antiproliferative activity is likely a consequence of its interaction with DNA. ${ }^{[20]}$ We envisioned reprogramming the cellular fate of rhodium by attaching a traceable molecule known to target DNA and we selected the common nuclear staining dye Hoechst 33258 for proof-of-concept (entry 4, Table 1). Indeed we were very pleased to find that after $30 \mathrm{~min}$ of incubation with a $100 \mu \mathrm{M}$ solution, fluorescence microscopy revealed the accumulation of $\mathbf{1 9}$ in cell nuclei of live U87 brain tumor cells (Figure 2).

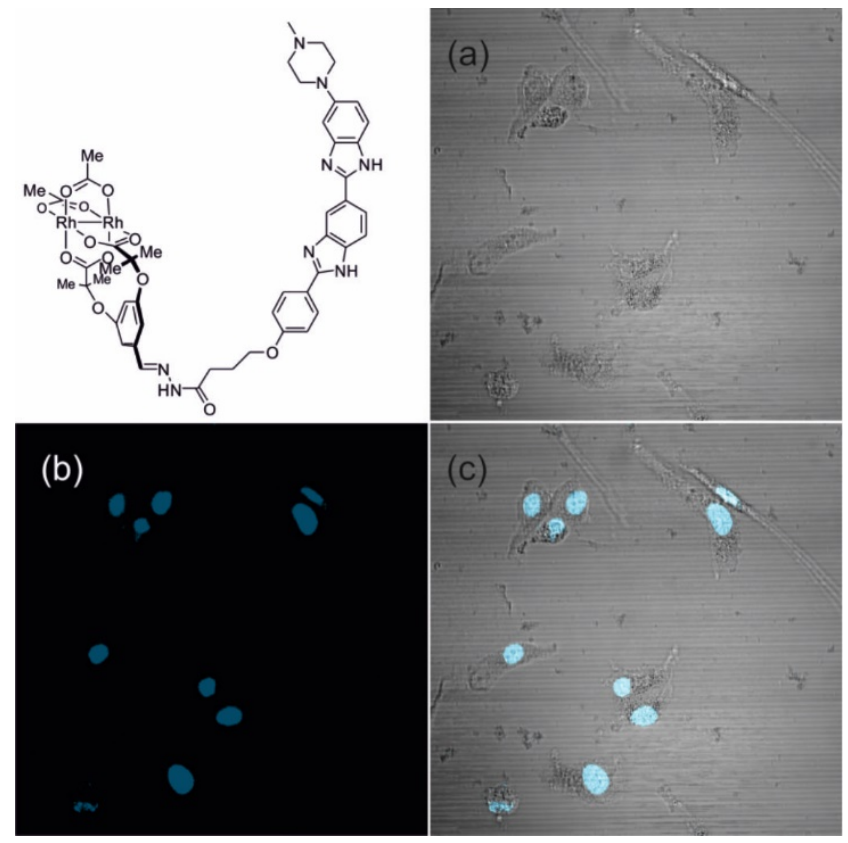

Figure 2. Selective Rh(II) complex uptake into cell nuclei of live U87 cells: (a) cells under white light, (b) cell nuclei stained by complex 19b, (c) overlay. See the ESI page S24 for a full description of the staining protocol and control experiments.

The strapped bidentate ligands were an important development for dirhodium(II) chemistry; ${ }^{[3,5,7]}$ here we add the innovation of a modular handle to this class of catalysts. The modularity facilitates rapid bespoke customization, as demonstrated by the reactions in Scheme 3 and the new catalysts in Table 1 . We are currently exploring the potential biological applications of the catalysts described in Table 1. But the ability to redirect dirhodium catalysts to the cell nucleus through simple Hoechst conjugation is already indicative of the enabling power of modular ligands. Now that we can localize rhodium to DNA the next step is to understand whether this specificity impacts rhodium's anti-cancer properties.

\section{Experimental Section}

Representative rhodium complex synthesis (3): Diacid 10e (20 mg, $0.055 \mathrm{mmol}$ ) was added into a dry round bottom flask under a nitrogen atmosphere as a solution in EtOAc and all volatiles were subsequently removed under reduced pressure. Then $2 \mathrm{ml}$ of 1,2dichloroethane were added and followed by $\mathrm{Rh}(\mathrm{OAc})_{2}(\mathrm{TFA})_{2}$ (30 mg, $0.055 \mathrm{mmol}$ ). The green solution was immersed into a preheated oil bath at $60^{\circ} \mathrm{C}$ and stirred for $7 \mathrm{~h}$. At this time most of the ligand was consumed and the amount of by-products was lowest compared to desired complex 3. After cooling to room temperature, all volatiles were removed under reduced pressure. The obtained green solid was subsequently dissolved in $1 \mathrm{~mL}$ of DMSO and injected into the preparative HPLC $\left(0.1 \%\right.$ TFA in $\mathrm{H}_{2} \mathrm{O}, 2 \%$ to $70 \% \mathrm{CH}_{3} \mathrm{CN}$ over $30 \mathrm{~min} . \mathrm{t}_{\mathrm{R}}=27 \mathrm{~min}$ ) and the product eluted as a purple band. After lyophilisation, $10 \mathrm{mg}$ $(0.015 \mathrm{mmol}, 27 \%)$ of $\mathbf{3}$ were obtained as a green solid. $3 \mathrm{mg}$ of $\mathrm{Rh}_{2}(\mathrm{OAc})_{2}(\mathrm{TFA})_{2}\left(\mathrm{t}_{\mathrm{R}}=26 \mathrm{~min}\right)$ were reisolated. ${ }^{1} \mathrm{H}$ NMR $(500 \mathrm{MHz}, 5 \% \mathrm{v} / \mathrm{v} \mathrm{MeOH}$ in $\left.\mathrm{CDCl}_{3}\right): \delta 6.67(\mathrm{~d}, \mathrm{~J}=2.1 \mathrm{~Hz}, 2 \mathrm{H}), 5.93(\mathrm{t}, \mathrm{J}=2.1 \mathrm{~Hz}$, $1 \mathrm{H}), 1.89$ (s, 6H), 1.36 (s, 12H). ${ }^{13} \mathrm{C}$ NMR (126 MHz, $5 \% \mathrm{v} / \mathrm{v} \mathrm{MeOH}$ in $\left.\mathrm{CDCl}_{3}\right): \delta 192.5,191.7,156.4,121.8$, 118.1, 107.7, 81.1, 25.0, 23.6. HRMS (ESI) m/z: calcd. for $\mathrm{C}_{18} \mathrm{H}_{21} \mathrm{BrO}_{10} \mathrm{Rh}_{2} \mathrm{Na}+[\mathrm{M}+\mathrm{Na}]+704.8320$ found: 704.8311.

Representative C-H insertion (14a): To a solution of diazo 13a (20.8 mg, $68.3 \mu \mathrm{mol})$ in $\mathrm{CH}_{2} \mathrm{Cl}_{2}(405.4 \mu \mathrm{L})$ a stock solution of $5\left(278.8 \mu \mathrm{L}, 4.91 \mathrm{mM}\right.$ in $\mathrm{CH}_{2} \mathrm{Cl}_{2}$, 2 mol \%) was added and the reaction mixture was stirred at rt. Analysis of the mixture via ${ }^{1} \mathrm{H}-\mathrm{NMR}$ spectroscopy after 10 min showed full conversion of the starting material to the single cis $\beta$-lactam 14a. The solvent was removed under reduced pressure and the residue was purified by flash chromatography (10 g $\mathrm{C}_{18}$ reverse phase silica, MeCN/0.1\% TFA in $\mathrm{H}_{2} \mathrm{O}$ ). The corresponding fractions were combined, the solvent removed under reduced pressure to obtain $\beta$ lactams 14a and 15a (14.3 mg, $51.7 \mu \mathrm{mol}, 76 \%$ ) as white solid. These could be further separated by preparative reverse phase HPLC. Characterization for 14a: ${ }^{1} \mathrm{H}-\mathrm{NMR}\left(400 \mathrm{MHz}, \mathrm{CDCl}_{3}\right) \delta 7.47-7.31(\mathrm{~m}$, $5 \mathrm{H}), 4.90$ (d, J = 6.3 Hz, 1H), 4.21 (d, J = $6.2 \mathrm{~Hz}, 1 \mathrm{H})$, $3.76(\mathrm{q}, \mathrm{J}=7.1 \mathrm{~Hz}, 2 \mathrm{H}), 1.31(\mathrm{~s}, 9 \mathrm{H}), 0.84(\mathrm{t}, \mathrm{J}=7.1$ $\mathrm{Hz}, 3 \mathrm{H}, 14 \mathrm{a}) .{ }^{13} \mathrm{C}-\mathrm{NMR}(101 \mathrm{MHz}, \mathrm{CD} 2 \mathrm{Cl} 2) \delta 166.6$, 163.3, 137.6, 129.1, 128.8, 127.8, 61.3, 59.6, 57.0, 55.328 .3 . 
For complete experimental details please see the electronic supplementary information.

\section{Acknowledgements}

We gratefully acknowledge Mr. Martin Nussbaumer for assistance with cell culture and live-cell imaging, Dr. Daniel Häussinger for measuring and interpreting high-field 2D NMR spectra, and Dr. Heinz Nadig for recording high resolution ESI mass spectra.

\section{References}

[1] K. Tishinov, K. Schmidt, D. Häussinger, D. G. Gillingham, Angew. Chem. Int. Ed. 2012, 51, 12000-12004.

[2] a) P. K. Sasmal, S. Carregal-Romero, A. A. Han, C. N. Streu, Z. Lin, K. Namikawa, S. L. Elliott, R. W. Köster, W. J. Parak, E. Meggers, ChemBioChem 2012, 13, 11161120; b) P. K. Sasmal, C. N. Streu, E. Meggers, Chem. Commun. 2013, 49, 15811587; c) T. Völker, F. Dempwolff, P. L. Graumann, E. Meggers, Angew. Chem. Int. Ed. 2014, 53, 10536-10540; d) Y. M. Wilson, M. Dürrenberger, E. S. Nogueira, T. R. Ward, J. Am. Chem. Soc. 2014, 136, 8928-8932; e) K. K. Sadhu, N. Winssinger, Chem. Eur. J. 2013, 19, 8182-8189.

[3] H. M. L. Davies, N. Kong, Tetrahedron Lett. 1997, 38, 4203-4206.

[4] H. T. Chifotides, K. R. Dunbar, Accounts Chem Res 2005, 38, 146-156.

[5] C. G. Espino, K. W. Fiori, M. Kim, J. Du Bois, J. Am. Chem. Soc. 2004, 126, 1537815379.

[6] a) J. Bickley, R. Bonar-Law, T. McGrath, N. Singh, A. Steiner, New J. Chem. 2004, 28, 425-433; b) J. F. Bickley, R. P. BonarLaw, C. Femoni, E. J. MacLean, A. Steiner, S. J. Teat, J. Chem. Soc., Dalt. Trans. 2000, 4025-4027; c) R. P. BonarLaw, T. D. McGrath, N. Singh, J. F. Bickley, C. Femoni, A. Steiner, J. Chem. Soc., Dalt. Trans. 2000, 4343-4347; d) R. P. Bonar-Law, T. D. McGrath, N. Singh, J. F. Bickley, A. Steiner, Chem. Commun. 1999, 2457-2458.

[7] D. F. Taber, R. P. Meagley, J. P. Louey, A. L. Rheingold, Inorg. Chim. Acta 1995, 239, 25-28.
[8] K. D. Collins, F. Glorius, Nature Chem. 2013, 5, 597-601.

[9] D. N. Zalatan, J. Du Bois, J. Am. Chem. Soc. 2009, 131, 7558-7559.

[10] M. Grohmann, G. Maas, Tetrahedron 2007, 63, 12172-12178.

[11] a) N. R. Candeias, C. Carias, L. F. R. Gomes, V. André, M. T. Duarte, P. M. P. Gois, C. A. M. Afonso, Adv. Synth. Catal. 2012, 354, 2921-2927; b) N. R. Candeias, P. M. P. Gois, C. A. M. Afonso, J. Org. Chem. 2006, 71, 5489-5497.

[12] J. M. Antos, M. B. Francis, J. Am. Chem. Soc. 2004, 126, 10256-10257.

[13] Z. T. Ball, Acc. Chem. Res. 2012, 46, 560570.

[14] a) F. Vohidov, J. M. Coughlin, Z. T. Ball, Angew. Chem. Int. Ed. 2015

DOI: 10.1002/ange.201411745; b) J. M. Antos, J. M. McFarland, A. T. Iavarone, M. B. Francis, J. Am. Chem. Soc. 2009, 131, 6301-6308; c) N. Fei, D. Haussinger, S. Blumli, B.-J. Laventie, L. D. Bizzini, K. Zimmermann, U. Jenal, D. Gillingham, Chem. Commun. 2014, 50, 8499-8502.

[15] a) J. M. Zimbron, T. Heinisch, M. Schmid, D. Hamels, E. S. Nogueira, T. Schirmer, T. R. Ward, J. Am. Chem. Soc. 2013, 135, 5384-5388; b) P. J. Deuss, G. Popa, C. H. Botting, W. Laan, P. C. J. Kamer, Angew. Chem. Int. Ed. 2010, 49, 5315-5317.

[16] Y. I. Hassan, J. Zempleni, J. Nutr. 2006, 136, 1763-1765.

[17] P. S. Low, A. C. Antony, Adv. Drug Deliv. Rev. 2004, 56, 1055-1058.

[18] W. J. Guo, G. H. Hinkle, R. J. Lee, J. Nucl. Med. 1999, 40, 1563-1569.

[19] B. Peña, R. Barhoumi, R. C. Burghardt, C. Turro, K. R. Dunbar, J. Am. Chem. Soc. 2014, 136, 7861-7864.

[20] a) J. D. Aguirre, A. M. Angeles-Boza, A. Chouai, J.-P. Pellois, C. Turro, K. R. Dunbar, J. Am. Chem. Soc. 2009, 131, 11353-11360; b) J. L. Bear, H. B. Gray, Jr., L. Rainen, I. M. Chang, R. Howard, G. Serio, A. P. Kimball, Cancer Chemother. Rep. Part 1 1975, 59, 611-620. 


\section{COMMUNICATION}

Modular ligands for dirhodium complexes facilitate catalyst customization

Adv. Synth. Catal. Year, Volume, Page - Page

Daniel G. Bachmann, Pascal J. Schmidt, Stefanie N. Geigle, Antoinette Chougnet, Wolf-Dieterich Woggon, and Dennis G. Gillingham*

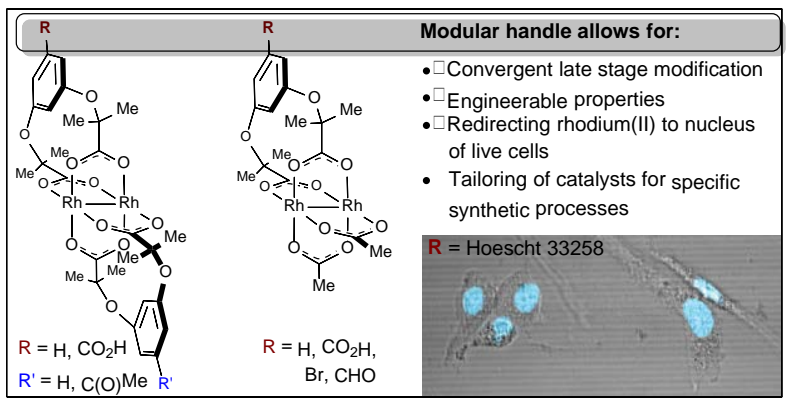

